DOI 10.18551/rjoas.2021-12.25

\title{
EFFECT OF PROBIOTICS IN WATER QUALITY MANAGEMENT OF KOI FISH (CYPRINUS CARPIO) INFECTED WITH MYXOBOLUS SP.
}

\author{
Djaduk Saddam Langkung * \\ Master's Study Program, Department of Aquaculture, Faculty of Fisheries and Marine \\ Science, University of Brawijaya, Indonesia \\ Yanuhar Uun, Awaludin Asep \\ Department of Aquatic Resource Management, Faculty of Fisheries and Marine Science, \\ University of Brawijaya, Indonesia \\ *E-mail: saddamld@student.ub.ac.id
}

\begin{abstract}
Koi fish (Cyprinus carpio) is an ornamental fish that is very popular in national and international markets. However, in the cultivation process to produce the best quality, many obstacles occur, one of which is the parasite Myxobolus sp. which are commonly found in Koi Fish (Cyprinus carpio) aquaculture ponds. Myxobolus sp. can cause mass deaths in a short time. Myxobolus sp. also attack organs in tissues that can cause various damage. Many ways have been achieved by cultivators in preventing the spread of these parasites, one of which is the use of probiotics. This study aims to determine the effect of giving probiotics as an effort to manage air quality and determine the effect on histopathological organs in fish as a form of preventing infection with the parasite Myxobolus sp. The method used is a method using control fish, treatment control, and experimental treatment of probiotics with doses of $0.6 \mathrm{ml}, 1.2 \mathrm{ml}, 1.6 \mathrm{ml}$ in healthy fish and sick fish as treatment $1,2,3,4,5.6$. Sampling of air quality using a $\mathrm{DO}$ meter and $\mathrm{pH}$ meter while for fish surgery using a sectio set, as well as making microscopic histopathological observations. The results of air temperature quality obtained an average of $25.50 \mathrm{C}$, an average $\mathrm{pH}$ of 8.17 , an average of $6.7 \mathrm{mg} / \mathrm{l} \mathrm{DO}$. The results of macroscopic and microscopic observations stated that the bacterial isolates in the probiotic Petrofish were species of Bacillus pumilus, Lactobacillus plantarum and Nitrosomonas sp. The results showed that there were changes and tissue damage in Koi Fish (Cyprinus carpio) infected with Myxobolus sp. The conclusion of this study is that the administration of probiotics can affect the air quality in the culture media and affect the histopathological changes of Koi Fish (Cyprinus carpio) tissue.
\end{abstract}

\section{KEY WORDS}

Cyprinus carpio, Myxobolus sp., probiotic.

Indonesia Improvement of Koi Fish (Cyprinus carpio) is a class of freshwater ornamental fish that has a fairly high price. The current ornamental fish from year to year has increased the value of exports which tend to continue to increase. Every month, about tens of millions of ornamental fish are exported to foreign countries so that ornamental fish commodities are able to contribute quite a lot of foreign exchange. The world trade in ornamental fish reaches 1,600 species and about $46 \%$ (750 species) comes from fresh water (Dahruddin, 2011). Koi fish (Cyprinus carpio) is in great demand by ornamental fish cultivators because it is a freshwater fish that is easy to cultivate.

Environmental systems are also related to water quality. Water quality is critical to the success of fish rearing management. More than $80 \%$ of the problems faced by koi farmers are water quality. The cause of the decline in water quality comes from several factors such as feces, undigested feed residue and metabolite waste. This can be seen from the decline in water quality due to the rapid increase in water $\mathrm{pH}$ and high levels of ammonia in maintenance. Such water quality can lead to the development of germs, lack of oxygen and even poisoning and death (Silaban, 2012). In addition, a drastic decrease and increase in 
temperature can disrupt the life of aquatic biota, one of which is the Koi Fish (Cyprinus carpio). In the cultivation of Koi Fish (Cyprinus carpio) poor quality greatly affects the development of Koi Fish (Cyprinus carpio), such as the color of the Koi Fish (Cyprinus carpio) turning pale, lack of oxygen and poisoning. The cause of poor water quality is also one of the causes of Koi Fish (Cyprinus carpio) to be stressed which can lead to a decrease in the immune system so that Koi Fish (Cyprinus carpio) are susceptible to disease (Agus et al., 2002).

Myxobolus sp. caused by parasitic attack where there are Myxobolus sp. or cysts on the gill sheets make Koi Fish (Cyprinus carpio) attacked by Myxobolus sp. shows symptoms of difficulty in breathing which then causes death in Koi Fish (Cyprinus carpio) which reaches up to $90 \%$ (Mahasri, 2017). Another clinical symptom of heavily infected Koi (Cyprinus carpio) is the inability to close the operculum. Mechanism of Myxobolus sp. When eaten by the fish, the spores will automatically break and release sporoplasm where the sporoplasm enters the body stream by moving amoeboidally and carried throughout the body tissues to the target organ (Hoole et al., 2001). Myxobolus sp. is a typical intracellular parasite of muscle cells, the spores of which are found in other organs. Spores will spread to organs through blood circulation (Maftuch, 2017).

Koi fish (Cyprinus carpio) cultivators have carried out various methods with the aim of preventing infection from this parasite using natural treatment or by giving probiotics. Water quality management in ponds is carried out by giving probiotics which aims to improve and maintain water quality, good water quality reduces stress levels in fish, and therefore it can improve the overall performance of the immune system and reduce the level of infection of opportunistic parasitic pathogens. Parasites show reduced infection rates when water quality is maintained at a constant high level. Therefore, aquatic probiotics can act as a preventive measure against parasitic infections (Brunner, 2019). The purpose of this study was to determine the status of water quality in the treatment of fish infected with Myxobolus sp. with probiotic treatment.

\section{MATERIALS AND METHODS OF RESEARCH}

Fish Sample And Test In Vivo. Koi fish (Cyprinus carpio) samples for this study were taken from Koi fish (Cyprinus carpio) farmers in Nglegok village, Kemloko sub-district, Blitar district, East Java. Koi fish (Cyprinus carpio) used as fish samples were taken from fish ponds infected with Myxobolus sp with fish size 7-12 cm. The collection of fish to be used as samples is done by looking at the clinical symptoms of fish infected with Myxobolus sp. for each sample fish used. This study used an experimental method with 8 test treatments, namely treatment (K-) control (healthy fish), $(\mathrm{K}+)$ control of fish infected with Myxobolus sp. (C) treatment of healthy fish with probiotics with 3 different doses $(0.60 \mathrm{ml}, 1.2 \mathrm{ml}, 1.8 \mathrm{ml})$, and treatment (D) Fish infected with Myxobolus sp. by giving probiotics with 3 different doses $(0.60 \mathrm{ml}, 1.2 \mathrm{ml}, 1.8 \mathrm{ml})$. The treatment of giving probiotics is done by pouring it directly into the water according to the dose used. The maintenance of the test fish samples was carried out in rearing tanks with the number of samples per tank of 10 fish.

Observation of Temperature and DO (Dissolved Oxygen). Sampling of water quality was carried out once during the observation. Sampling of temperature and DO water quality uses a DO meter with the Lutron PDO-519 DO meter brand made in Taiwan.

Observation of $\mathrm{pH}$ (Power of Hydrogen). Sampling of water quality was carried out once during the observation. Taking samples of $\mathrm{pH}$ water quality using a tool in the form of a $\mathrm{pH}$ meter with the Digital ATC brand made in Taiwan.

Bacteria Identification. Observations of bacteria were carried out in 4 stages. The first step was making agar media, the initial stage in making media was using sterile MRS agar (MRSA) selective media. Then proceed with the isolation of bacteria, the isolation of bacteria is carried out in accordance with the Indonesian National Standard (SNI) ISO 68871: 2012. The next step is identification of bacteria, for identification of bacteria, Gram staining is carried out on bacteria that have been purified. The last is data analysis, the data obtained 
are analyzed descriptively by using a series of words, pictures, tables to the results of observations.

Histopathological Observations. Histopathological observation procedures on Koi Fish (Cyprinus carpio) refer to Oktava et al (2017), as follows:

- Fixation Stage. The sample to be observed is taken from the tissue. The tissue that has been taken is then immersed in a 10\% formalin solution for 24 hours;

- Dehydration Stage. At this stage, drying or water withdrawal is carried out using a tool called an autotechnicon for 20 hours. Autotechnicon consists of $70 \%$ alcohol for 1 hour, 90\% alcohol for 2 hours, $80 \%$ alcohol for 1 hour, 96\% alcohol for 2 hours, absolute alcohol 1 for 2 hours and absolute alcohol 2 for 2 hours;

- Clearing Stage. This stage serves to transparent and replace the alcohol solution and tissue. By immersing in a solution of xylol 1 for 1 hour, xylol 2 for 2 hours and xylol 3 for 2 hours;

- Impregnation Stage. At this stage, the material is immersed in paraffin with the aim of equating the state of the network with embedding. Immersion into paraffin at a temperature of $56-60^{\circ} \mathrm{C}$ for 2 hours and repeated 2 times;

- Embedding Stage (Blocking). The purpose of Embedding is to facilitate the incision process using a microtome;

- Tissue Staining Technique Using HE (Hematoxylin Eosin). Staining using HE has several stages, namely deparaffinization, hydration, main paint, dehydration and clearing;

- Mounting Stage. The mounting stage is the last procedure in a series of preparations before being observed macroscopically and microscopically which aims to facilitate the observation.

\section{RESULTS AND DISCUSSION}

Symptoms of Koi Fish (Cyprinus carpio) Infected with Myxobolus sp. Clinical symptoms of fish infected with Myxobolus sp. It can be seen by observing the gills indicated by the presence of spots with red and white spots on the fish gills. White patches on the gills occur due to necrosis (death) of the gill tissue. In addition, the symptoms of Myxobolus sp. in fish, namely the presence of lumps (boils) on the gills and discharge a reddish, cloudy liquid like pus. Nodules found on the gills will interfere with the supply of oxygen to the blood, the condition of the fish will get worse when the nodules break, causing tissue necrosis due to impaired respiratory function (Insivitawati et al., 2017).

Fish that show clinical symptoms in the form of an operculum that cannot close completely and the incidence of mortality is high in young fish. Spores of Myxobolus sp. form capsules / nodules, usually attacking the gills, brain, eyes and skin. Parasites can generally cause death by showing clinical symptoms. Parasite attacks can also cause damage to the host's organs (Priyono, 2012).

Diagnosis of Myxobolus sp. Fish attacked by Myxobolus sp. will show clinical symptoms of reddish white nodules on the gills, which contain a collection of thousands of spores. Another clinical symptom seen is the operculum that cannot close if the fish is heavily infected (Hoole et al., 2001). Koi fish (Cyprinus carpio) infected with Myxobolus sp. Usually the breathing process will be disturbed, besides the presence of nodules on the gills will make the fish lose balance and cause the fish to swim spirally from the bottom to the surface of the water.

The impact of Myxobolus sp. depending on the degree of infection and the location of the cyst. Large infections that occur in the gills cause tissue death (necrosis) and respiratory failure. Infections that occur in the intestine will cause myolitics on the intestinal wall (Sugianti et al., 2005). The clinical symptoms of Myxosporeiasis are almost the same, namely fish swimming unbalanced, the operculum always opens, circular swimming movements from bottom to top (whirling diseases), fish swimming close to the surface of the water which may 
be caused by Koi Fish (Cyprinus carpio) having difficulty breathing due to colored nodules. white on the gill filaments (Prihartini and Alfiyah, 2017).

According to Firmansyah (2012), there are three categories or degrees of infection caused by the parasite Myxobolus sp. namely light scale, medium scale and heavy scale. The number of Myxobolus sp. used as a basis for determining the degree of infection. The number of Myxobolus sp. nodules. classified into the degree of mild infection, namely 1-4 nodules, 5-8 nodules included in moderate infection, and nodules more than 8 classified as severe infection. Nodules were counted according to the nodules on the gills, nodules from small to large were counted the same, nodules were counted from two sides of the operculum.

Temperature Observation Results. Based on the results of temperature observations in this study, the results of $\mathrm{K}+$ in test 1 were $25.7^{\circ} \mathrm{C}$, test 2 was $25.4^{\circ} \mathrm{C}$, and replicated 3 was $25.5^{\circ} \mathrm{C}$. K- on repetition 1 was $25.3^{\circ} \mathrm{C}$, repetition 2 was $25.4^{\circ} \mathrm{C}$ and replicated 3 was $25.5^{\circ} \mathrm{C}$. $\mathrm{P} 1$ in replication 1 was $25.9^{\circ} \mathrm{C}$, in test 2 was $25.4^{\circ} \mathrm{C}$, and in test 3 was $25.8^{\circ} \mathrm{C}$. P2 on replication 1 was $25.6^{\circ} \mathrm{C}$, replication 2 was $25.5^{\circ} \mathrm{C}$ and replicated 3 was $25.7^{\circ} \mathrm{C}$. P3 in the 1 st test was $25.4^{\circ} \mathrm{C}$, the 2 nd test was $25.7^{\circ} \mathrm{C}$, and the $3 r d$ test was $25.7^{\circ} \mathrm{C}$. P4 in replication 1 was $25.7^{\circ} \mathrm{C}$, replicated 2 was $25.6^{\circ} \mathrm{C}$ and replicated 3 was $25.7^{\circ} \mathrm{C}$. P5 in replication 1 was $25.4^{\circ} \mathrm{C}$, in test 2 was $25.5^{\circ} \mathrm{C}$, and replicated 3 was $25.4^{\circ} \mathrm{C}$. P6 in test 1 was $25.9^{\circ} \mathrm{C}$, in test 2 was $25.5^{\circ} \mathrm{C}$ and test 3 was $25.3^{\circ} \mathrm{C}$. The highest temperature results were found in treatment $\mathrm{P} 1$ replication 1 and $\mathrm{P} 6$ replication 2 with a temperature of $25.9^{\circ} \mathrm{C}$, while the lowest temperature was obtained in $\mathrm{K}$ - replication 1 and $\mathrm{P} 6$ replication 3 with a temperature of $25.3^{\circ} \mathrm{C}$.

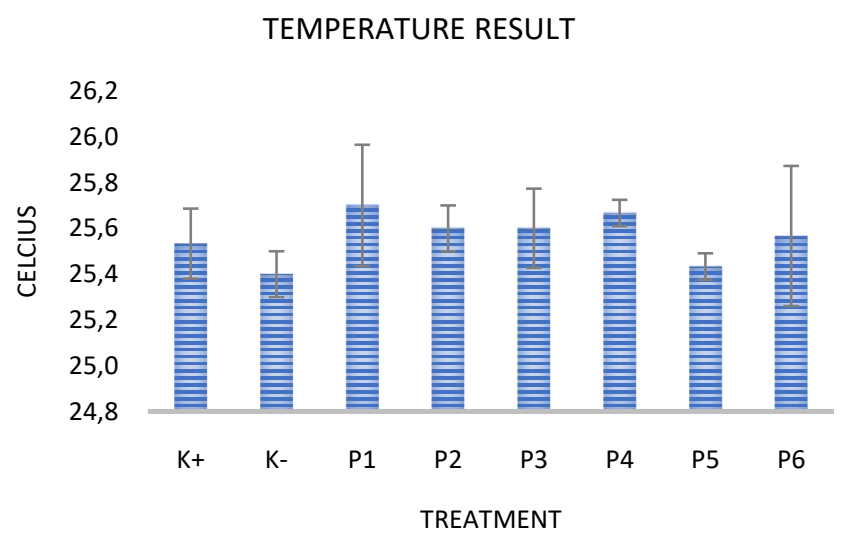

Figure 1 - Graph of temperature calculation results. There were 8 treatments with 3 replications, with 3 different doses of $0.60 \mathrm{ml}, 1.2 \mathrm{ml}$, and $1.8 \mathrm{ml}$. The highest temperature is $25.9 \mathrm{C}$ and the lowest temperature is $25.3 \mathrm{C}$.

Based on the results of observations of water quality samples on the first day of observation, the lowest temperature was obtained at $25.3^{\circ} \mathrm{C}$. Meanwhile, the highest temperature was $25.9^{\circ} \mathrm{C}$. This research was conducted indoors so that changes in outside temperature have little effect on the water media. During the study there were no extreme temperatures in the media water, so that the death of fish was entirely caused by the treatment of Myxobolus sp. This controlled temperature is in accordance with the statement of Kolabora (2010), the optimal temperature for koi fish growth is $25^{\circ} \mathrm{C}-27^{\circ} \mathrm{C}$. According to Saputra (2017), in this range oxygen consumption reaches $2.2 \mathrm{mg} / \mathrm{g}$ body weight-hour. Below $25^{\circ} \mathrm{C}$, oxygen consumption reaches $1.2 \mathrm{mg} / \mathrm{g}$ body weight-hour. Environmental temperature affects the growth and metabolism of koi fish. High water temperatures can result in most of the energy stored in the fish's body being used for adaptation to an unfavorable environment, so that it can damage the metabolic system or exchange of substances. In addition, at the optimum temperature for fish will increase the growth of good fish. 


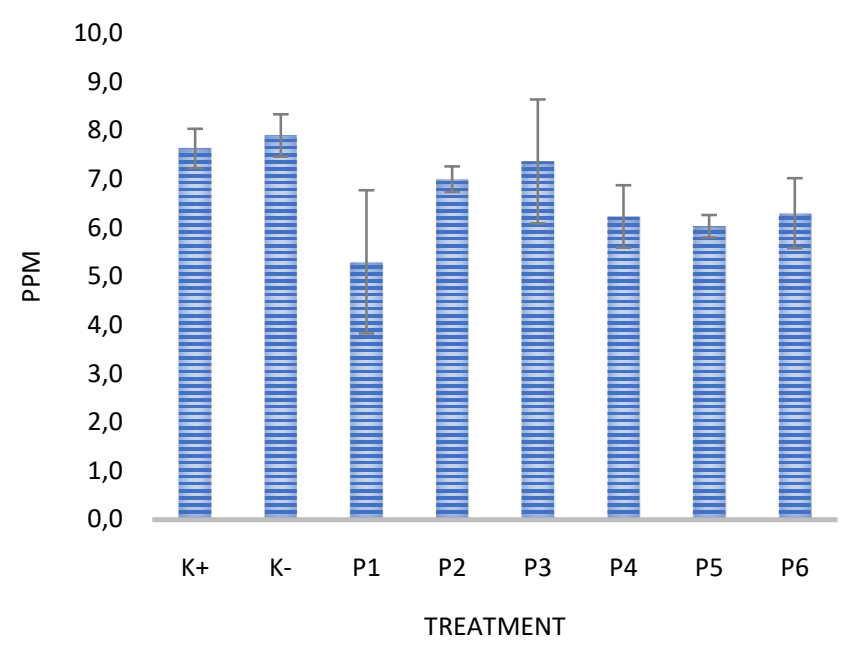

Figure 2 - The graph of DO calculation results. There were 8 treatments with 3 replications, with 3 different doses of $0.60 \mathrm{ml}, 1.2 \mathrm{ml}$, and $1.8 \mathrm{ml}$. The highest DO is 8.2 while the lowest DO is 3.7 .

Dissolved Oxygen Observation Results. Based on the results of DO observations in this study, the results of the $\mathrm{K}+$ on the 1 st test were 7.7 , the 2 nd test was 7.2 , and the $3 \mathrm{rd}$ was 8 . $\mathrm{K}$ - in the 1 st test was 7.4 , the 2 nd test was 8.2 and 3 is 8.1 . P1 on test 1 was 3.7 , in test 2 was 6.6, and in test 3 was 5.6. P2 in test 1 was 7.1 , in test 2 was 7.2 and in test 3 was 6.7. P3 on the 1st test was 8.2, 2nd was 8 and 3rd was 5.9. P4 on the 1st test was 6.7, the 2nd test was 6.5 and the 3rd test was 5.5. P5 on the 1st test was 5.9, the 2 nd test was 6.3 , and the 3rd test was 5.9. P6 on the 1st test was 7.1, the 2nd test was 6.1 and the 3rd test was 5.7. The highest DO results were found in K-repetition 2 and P3 treatment 1 with a DO of 8.2, while the lowest DO was found in K-replication 1 with a DO of 3.7.

Based on the results of dissolved oxygen observations in the control tank, it is included in the oxygen level that is good for the maintenance of koi fish (Cyprinus carpio). Based on the observation of water quality samples, the lowest DO was 3.7. Meanwhile, the highest DO was 8.2. Dissolved oxygen conditions were different in each tank, although the results obtained were not significantly different. This is influenced by the utilization of aquatic organisms and the use of organic matter decomposition in the waters. This is in accordance with the statement of Irianto (2005) that the dissolved oxygen level that supports the growth and maintenance of koi fish is $>3 \mathrm{ppm}$. From the data above, it can be seen that there was no extreme low DO, because during the study, the media water was provided with sufficient aeration, namely dissolved oxygen in the range of 5-6 ppm, so that the death of fish was entirely due to the treatment of Myxobolus sp.

Power of Hydrogen Observation Results. Based on the results of $\mathrm{pH}$ observations in this study, the $\mathrm{K}+$ results in test 1 were 8.20 , in test 2 were 8.03 , and in test 3 was 8.22 . Kon the 1st test was 8.31 , the second test was 8.23 and the 3rd test was 8.22 . P1 on the 1 st test was 8.12 , the second test was 8.23 and the 3rd test was 8.16. P2 on the 1st test was 8.14 , the second test was 8.08 and the 3rd test was 8.22 . P3 on test 1 was 8.24 , in test 2 was 8.16 and in test 3 was 7.74. P4 on test 1 was 8.06 , test 2 was 7.94 and replicated 3 was 7.96. P5 on the 1st test was 8.23, the second test was 8.12, and the 3rd test was 8.10. P6 on test 1 was 8.52 , test 2 was 8.31 and replicated 3 was 8.18 . The highest $\mathrm{pH}$ results were found in $\mathrm{P} 3$ treatment with a $\mathrm{pH}$ of 8.52 , while the lowest $\mathrm{pH}$ was found in $\mathrm{P} 3$ replicates 3 with a $\mathrm{pH}$ of 7.74 . 


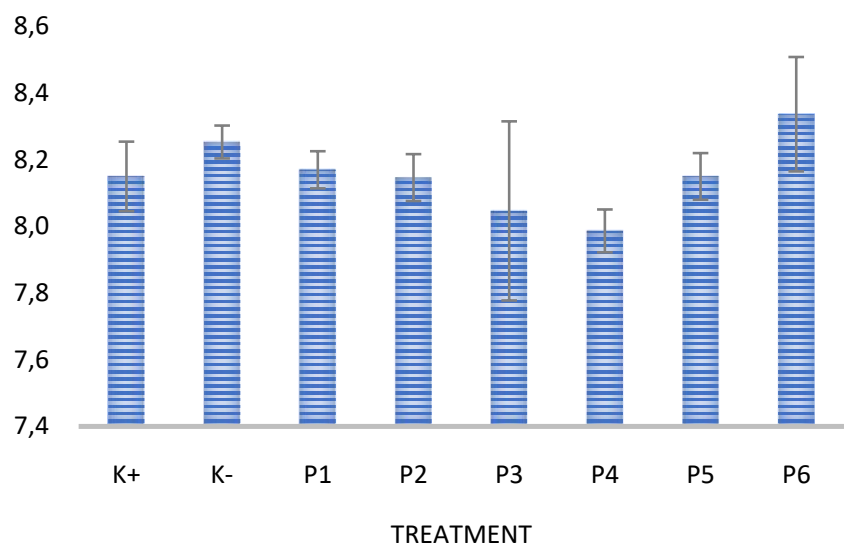

Figure 3 - Graph of pH calculation results. There were 8 treatments with 3 replications, with 3 different doses of $0.60 \mathrm{ml}, 1.2 \mathrm{ml}$, and $1.8 \mathrm{ml}$. The highest $\mathrm{pH}$ is 8.52 while the lowest $\mathrm{pH}$ is 7.74 .

The results of the measurements can be seen that the $\mathrm{pH}$ value in the experiment bath water is the highest at 8.52, while the lowest value is 7.74 . Based on the $\mathrm{pH}$ value obtained, this value is a $\mathrm{pH}$ value that can be tolerated by fish. This is in accordance with the statement of Zonneveld (1991), a suitable $\mathrm{pH}$ for fish life ranges from 6.5 to 8.0. At this $\mathrm{pH}$ value, there is no drastic change. This is in accordance with Siswanto's (2021) statement, which states that the ability of water to hold $\mathrm{pH}$ is more important than the $\mathrm{pH}$ value itself.

Table 1 - Petrofish probiotic sample biochemical test data (B1: Bacillus pumilus, L1: Lactobacillus plantarum, N1: Nitrosomonas sp.)

\begin{tabular}{|c|c|c|c|}
\hline \multirow{2}{*}{ Biochemical Test } & \multicolumn{3}{|c|}{ Results } \\
\hline & B1 & L1 & N1 \\
\hline Spora & + & - & - \\
\hline Oksidase & + & - & - \\
\hline Motilitas & - & + & + \\
\hline Nitrat & + & + & + \\
\hline Lysin & + & - & - \\
\hline Ornithin & - & - & - \\
\hline $\mathrm{H}_{2} \mathrm{~S}$ & - & - & - \\
\hline Glukosa & + & + & - \\
\hline Manitol & + & + & - \\
\hline Xylosa & - & + & - \\
\hline ONPG & - & + & + \\
\hline Indole & - & - & - \\
\hline Urease & - & + & - \\
\hline V-P & - & - & - \\
\hline Sitrat & + & + & + \\
\hline TDA & - & - & - \\
\hline Gelatin & - & - & - \\
\hline Malonat & - & - & - \\
\hline Inositol & - & - & - \\
\hline Rhamnosa & - & - & - \\
\hline Sukrosa & + & + & - \\
\hline Lactosa & - & + & - \\
\hline Arabinosa & + & - & - \\
\hline Adonitol & - & - & - \\
\hline Raffinosa & - & - & - \\
\hline Salicin & - & - & - \\
\hline Arginin & - & - & - \\
\hline Katalase & + & - & - \\
\hline Koagulase & - & - & - \\
\hline hemolisa & beta & gamma & gamma \\
\hline Uji sensitive Novobiosin & TDK & TDK & TDK \\
\hline Starch hydrolysis & + & TDK & TDK \\
\hline Casein hydrolysis & + & TDK & TDK \\
\hline
\end{tabular}


Bacteria Identification Results. Bacterial isolation is a technique used to obtain single colonies of bacteria. The results of the isolation and identification of bacteria with Petrofish probiotic samples were carried out using tests that included tests of spore, oxidase, motility, nitrate, lysine, indole, ONPG, xylose, mannitol, glucose, H2S, Ornithin, urease VP, citrate, TDA, gelatin, malonate, inositol, rhamnose, coagulase, catalase, arginine, salicin, raffinose, adonitol, arabinose, lactose, sucrose, starch hydrolysis, casein hydrolysis. With various identification results, it is stated that the bacterial isolates in Petrofish probiotics are species of Bacillus pumilus, Lactobacillus plantarum and Nitrosomonas sp.
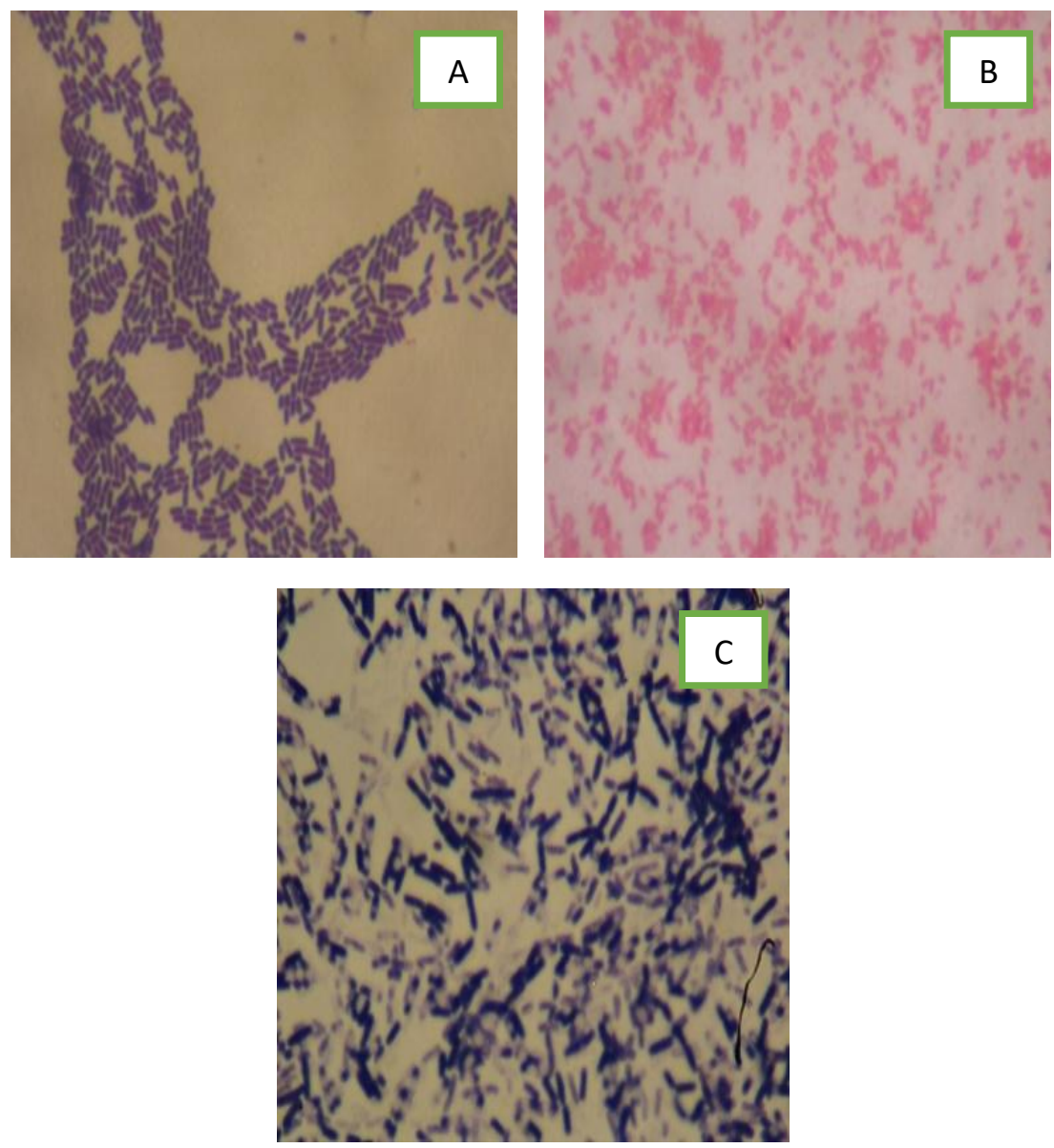

Figure 4 - Microscopic view of bacteria (A. Bacillus pumilus, B. Lactobacillus plantarum and C. Nitrosomonas sp.) on Petrofish probiotic samples

Histopathological Observations of Gills. Histopathological analysis can be used as a biomarker to determine the health status of fish through structural changes that occur in organs that are the main targets of pollutants such as gills, liver, kidneys, and others. (Dutta, 1996). The histopathological biomarkers can be used in environmental monitoring by observing organs that have important functions in the metabolism of organisms so that they can be used as an initial diagnosis of health disorders in organisms (Camargo, 2007). ). The gills are the respiratory organs in fish like the lungs in mammals or other land animals.

Based on the research that has been done, the histopathological description of the gill tissue of koi fish (Cyprinus carpio) was obtained from negative control, positive control and P1, P2, P3 treatments, namely fish infected with Myxobolus sp. with the administration of probiotics with a dose of $0.6 \mathrm{ml}, 1.2 \mathrm{ml}$ and $1.8 \mathrm{ml}$, respectively. While the treatments $\mathrm{P} 4, \mathrm{P} 5$, P6 were normal or healthy fish with the provision of probiotics with a dose of $0.6 \mathrm{ml}, 1.2 \mathrm{ml}$ and $1.8 \mathrm{ml}$, respectively. The following is a cross-section of the gill tissue of negative control koi fish, positive control and treatment P1, P2, P3, P4, P5, P6 observed in a binocular light microscope with 400x magnification as shown in Figure 5. 

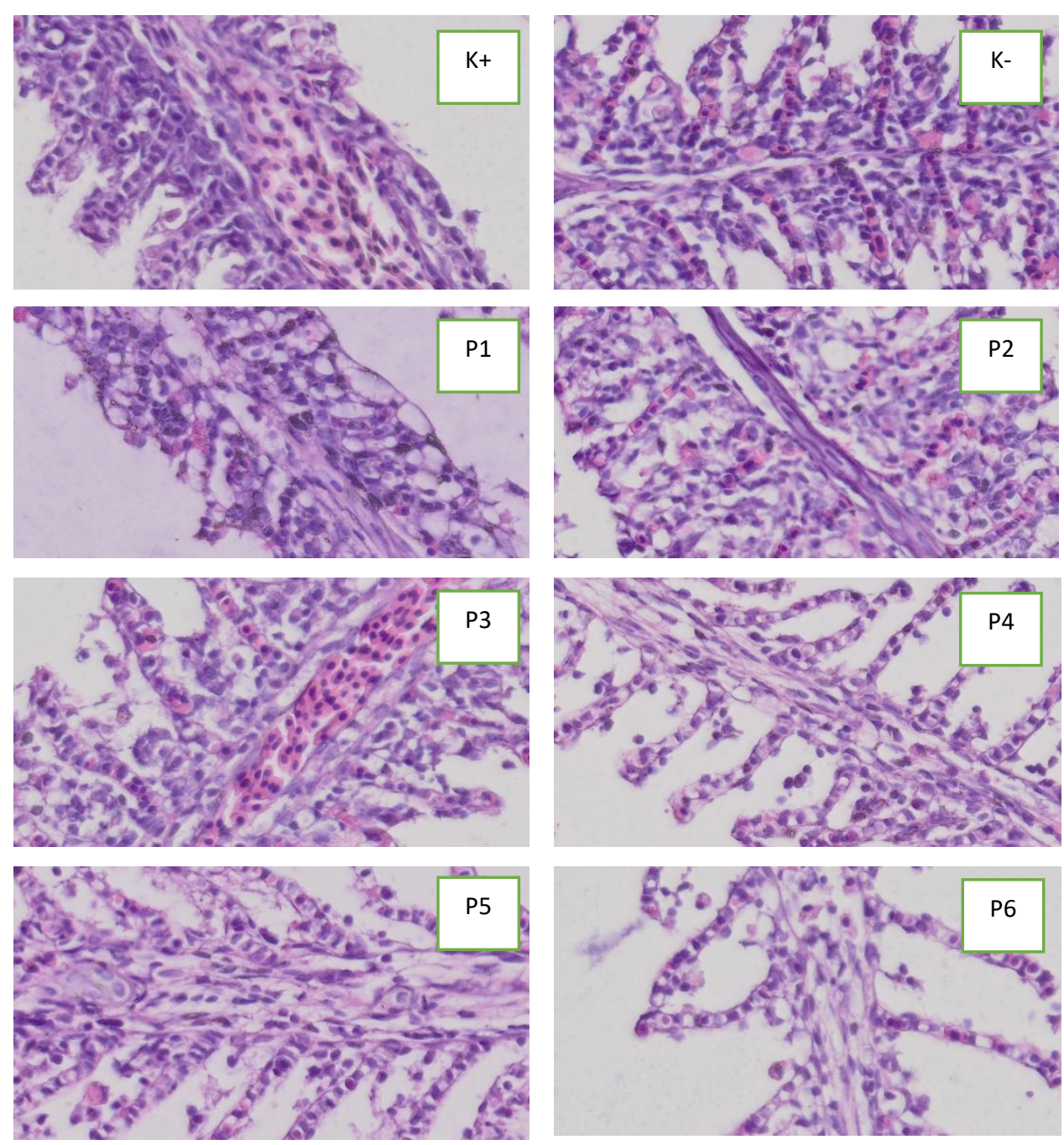

Figure 5 - Histopathological description of Koi Fish (Cyprinus carpio) gill tissue treatment $\mathrm{K}+, \mathrm{K}-, \mathrm{P} 1$, P2, P3, P4, P5, P6 with microscopic observation with 400x magnification, there are differences in edema tissue damage in each treatment.

The results showed a picture of the gill tissue of Koi Fish (Cyprinus carpio) with different doses of probiotics, showing different histopathological results in each fish. Although it is not seen directly that the administration of probiotics can affect tissue recovery, but the difference in damage that occurs to the gill tissue in two different fish conditions (healthy and infected fish).

\section{CONCLUSION}

The results of this study can be concluded that the provision of probiotics Petrofish with bacteria Bacillus pumilus, Lactobacillus plantarum and Nitrosomonas $\mathrm{sp}$. as a treatment for Myxobolus sp. can affect the status of changes in the histopathological tissue of fish, namely tissue damage. Probiotic treatment also affects the improvement of water quality to be optimal in the cultivation and maintenance of Koi Fish (Cyprinus carpio)..

\section{ACKNOWLEDGEMENTS}

Thank you to all those who have helped us completing this research, we hope this research is useful for many people. 


\section{REFERENCES}

1. Agus, G.T.K., Agus K.A., A. Dianawati, Dipo U.T., E.S. Irawan, K. Miharja, L. Gusyadi, Luluk A.M., Maman N., P.S. Karno, P. Dachlan, Udin S., Ujang J.M., T. Yana dan Y. Sastro. (2002). Koi. PT Agro Media Pustaka. Tangerang. Hal 23 - 46.

2. Brunner, S. (2019). Probiotics In Fish Aquaculture: The Cure Against Parasitic Diseases? $\mathrm{PhD}$ Thesis, University of Groningen. Retrieved from https://fse.studenttheses.ub.rug.nl/21227/.

3. Camargo, M. M., \& Martinez, C. B. (2007). Histopathology of gills, kidney and liver of a Neotropical fish caged in an urban stream. Neotropical Ichthyology, 5(3), 327-336.

4. Dahruddin, H. (2011). Ikan Botia Maskotnya Ekspor Ikan Hias Asli Indonesia. Fauna Indonesia. 1(1), 17-21.

5. Dutta, H.M., and J.S.D Munshi. 1996. Fish Morphology, Horrizon of New.

6. Firmansyah, R. A. F. (2012). Prevalensi Dan Jumlah Nodul Pada Insang Ikan Koi (Cyprinuscarpio) Yang Terinfeksi Myxobolus Di Sentra Budidaya Ikan Koikabupaten Blitar-Jawa Timur. Doctoral Dissertation, Universitas Airlangga. Retrieved From http://repository.unair.ac.id/26132/.

7. Hoole, D., D. Bucke., P. Burgess., and I. Wellby. (2001). Diseases of Carp and Other Cyprinid Fishes. Oxford, UK: Fishing News Books.

8. Hoole, D., D. Bucke., P. Burgess., and I. Wellby. (2001). Diseases of Carp and Other Cyprinid Fishes. Oxford, UK: Fishing News Books.

9. Insivitawati, E., G. Mahasri dan Kusnoto. (2015). Gambaran Darah Dan Histopatologi Insang, Usus Dan Otak Ikan Koi (Cyprinus carpio) Yang Diinfeksi Spora Myxobolus Koi Secara Oral. Jurnal IImiah Perikanan dan Kelautan. 7(2), 225 - 234.

10. Irianto, A. 2005. Patologi Ikan Teleostei. Gadjah Mada University press. Hal: 17-39.

11. Kordi, K.M.G. et al, 2007. Pengelolaan Kualitas Air dalam Budidaya Perairan. PT Rineka.

12. Maftuch, M., Sanoesi, E., Farichin, I., Saputra, B. A., Ramdhani, L., Hidayati, S., \& Prihanto, A. A. (2017). Histopathology of Gill, Muscle, Intestine, Kidney, and Liver on Myxobolus Sp. Infected Koi Carp (Cyprinus carpio). Journal of Parasitic Diseases. 42(1), 137-143.

13. Mahasri, G. (2017). Development of Spore Protein of Myxobolus koi as an Immunostimulant for Prevent of Myxobolusis on Gold Fish (Cyprinus carpio) by Oral Immunisation. Earth and Environmental Science. 55(1), 1-11.

14. Oktafa, U., Suprastyani, H., Handayani, S., Gumala, G. A., Fatikah, N. M., Wahyudi, M., \& Pratama, R. (2017). Pengaruh Pemberian Bakteri Lactobacillus plantarum Terhadap Histopatologi dan Hematologi Ikan Patin Jambal (Pangasius djambal) yang Diinfeksi Bakteri Edwarsiella tarda. Journal of Fisheries and Marine Research, 1(1), 31-38.

15. Prihartini, N. C., dan Alfiyah. (2017). Myxosporeasis Pada Ikan Koi (Cyprinus carpio). Jurnal Ilmu Perikanan. 8(1), 6-10.

16. Priyono, A., (2012). Penentuan Spesies Myxobolus Pada Ikan Air Tawar di Berbagai Pulau di Indonesia Secara Konvensional dan Molekuler. Universitas Gadjah Mada.

17. Research Science Publisher, Inc. USA.

18. Saputra, I. W. R. R., Restu, I. W., \& Pratiwi, M. A. (2017). Analisis Kualitas Air Danau sebagai Dasar Perbaikan Manajemen Budidaya Perikanan di Danau Buyan Kabupaten Buleleng, Provinsi Bali. Jurnal Ecotrophic, 11(1), 1-7.

19. Silaban, T. F., Santoso, L., Suparmono. (2012). Dalam Peningkatan Kinerja Filter Air Untuk Menurunkan Konsentrasi Amonia Pada Pemeliharaan Ikan Mas. E-Journal Rekayasa dan Teknologi Budidaya Perairan. 1(1), 47-56.

20. Siswanto, S., Sofarini, D., \& Hanifa, M. S. (2021). Kajian Fisika Kimia Perairan Danau Bangkau Sebagai Dasar Pengembangan Budidaya Ikan. Rekayasa, 14(2), 245-251.

21. Sugianti, B., R.C. Tarumingkeng., Z. Coto, dan Hardjanto. (2005). Pemanfaatan Tumbuhan Obat Tradisional Dalam Pengendalian Penyakit Ikan. Makalah Pribadi Falsafah Sains (PPS-702). Program Pasca sarjana. Institut Pertanian Bogor.

22. Zonneveld, N.E., E.A. Husmain and J.H. Boon. 1991. Prinsip - Prinsip Budidaya Ikan. Terjemahan. Jakarta. PT. Gramedia. 